ISSN : $2460-7797$

e-ISSN : 2614-8234

Website : jurnal.umj.ac.id/index.php/fbc

Email : fibonacci@umj.ac.id

\title{
PERSEPSI ORANG TUA TERHADAP KECERDASAN MAJEMUK ANAK
}

\author{
Viarti Eminita $^{1)^{*}}$, Arlin Astriyani ${ }^{2)}$ \\ Pendidikan Matematika, Universitas Muhammadiyah Jakarta, 15419 \\ *viarti.eminita2@umj.ac.id
}

\begin{abstract}
Abstrak
Selama ini banyak orang tua berpersepsi bahwa anak yang cerdas adalah anak-anak yang mendapatkan nilai yang tinggi dalam pelajaran disekolah terutama mata pelajaran matematika. Hampir sebagian besar orang tua melakukan kesalahan terhadap anak-anaknya. Kesalahan tersebut salah satunya karena persepsi atau ketidaktahuan orang tua dalam mendidik anak dengan benar. SD Labschool FIP UMJ memiliki misi membangun kecerdasan anak melalui kecerdasan majemuk. Misi ini juga harus didukung oleh orang tua siswa, sehingga peneliti tertarik untuk meneliti bagaimana persepsi orang tua terhadap kecerdasan majemuk anaknya. Adapun tujuan dalam penelitian ini adalah mendeskripsikan persepsi orang tua terhadap kecerdasan majemuk anaknya. Penelitian ini dilakukan dengan membandingkan antara harapan (dukungan) dan persepsi orang tua menggunakan metode survey. Jenis penelitian yang digunakan dalam penelitian ini adalah penelitian kuantitatif deskriptif. Populasi dalam penelitian ini adalah orang tua dari siswa SD Labschool FIP UMJ berjumlah 257. Penarikan sampel dalam penelitian ini menggunakan teknik penarikan sampel bertujuan dan sampel yang digunakan adalah 38 siswa dari 2 kelas yang dipilih. Terdapat 18 indikator pada instrumen yang tidak valid/dikeluarkan dari 88 indikator yang diujikan. Berdasarkan hasil analisis IPA yang dilakukan, diperoleh bahwa Tingkat Kesesuaian Total $\left(\right.$ Tk $_{i}$ Total) antara persepsi $(X)$ dengan dukungan (Y) adalah sebesar 94,9\%. Hal ini berarti bahwa antara dukungan dan harapan yang diberikan oleh orang tua terhadap kecerdasan majemuk anak sudah sesuai dengan persepsi atau performa kecerdasan majemuk anak. Kecerdasan majemuk yang masih perlu ditingkatkan bagi siswa adalah kecerdasan logismatematis anak. Performa kecerdasan ini masih sangat jauh dari dukungan dan harapan orang tua.
\end{abstract}

Kata Kunci: Kecerdasan Majemuk, Persepsi, Kecerdasan Logis-Matematis.

\section{PENDAHULUAN}

Orang tua merupakan sekolah pertama bagi anaknya, bahkan sejak anaknya masih didalam kandungan. Mereka sangat berperan penting dalam tumbuh kembang anaknya, salah satunya meningkatkan kecerdasan anak. Semua orang tua melakukan apapun agar anaknya menjadi cerdas, yakni menyekolahkan mereka ditempat yang baik. Selama ini banyak orang tua berpersepsi bahwa anak yang cerdas adalah anak-anak yang 
mendapatkan nilai yang tinggi dalam pelajaran disekolah terutama mata pelajaran matematika (Chatib, 2014), sehingga orang tua hanya mengembangkan sisi inteligensinya saja dibandingkan kecerdasan lainnya. Hal ini dapat mengakibatkan anak dapat mengalami gangguan psikologi.

Orang tua berperan selama 24 jam, seperti dalam penentuan kurikulum, silabus, materi dan pembelajaran anak, selain itu orang tua berperan aktif dalam melatih kemampuan life skill dan pemahaman agama pada anak (A'yun, Prihartanti, dan Chusniatun, 2015). Orang tua harus memiliki hobi baru, yaitu melakukan discovery ability kepada anaknya, menjelajah kemampuan anak meskipun sekecil debu (Chatib, 2014). Meningkatkan kecerdasan anak merupakan salah satu cara menjelajah kemampuan anak. Semua orang tua melakukan apapun agar anaknya menjadi cerdas, misalnya menyekolahkan anaknya ditempat yang baik, menciptakan suasana lingkungan belajar yang kondusif, mendampingi anak saat belajar, bahkan memberikan anaknya les tambahan.

Hampir sebagian besar orang tua melakukan kesalahan terhadap anakanaknya. Kesalahan tersebut salah satunya karena persepsi atau ketidaktahuan orang tua dalam mendidik anak dengan benar. Berdasarkan survei yang dilakukan oleh Federasi Kesehatan Mental Indonesia (FEKMI) pada 2003, mayoritas (82\%) remaja beranggapan bahwa orang tua otoriter, $50 \%$ mengaku pernah mendapatkan hukuman fisik, dan 39\% mengatakan orang tua pemarah (Noviarni, 2015).

Menurut Kamus Besar Bahasa Indonesia $(\mathrm{KBBI})$, persepsi adalah proses seseorang mengetahui beberapa hal melalui panca inderanya. Sedangkan dalam Kamus Besar Psikologi, persepsi diartikan sebagai suatu proses pengamatan seseorang terhadap lingkungan dengan menggunakan indra-indra yang dimiliki sehingga ia menjadi sadar akan segala sesuatu yang ada dilingkungannya. Pengertian persepsi menurut para ahli:

1. Slameto (2010:102) menjelaskan pengertian persepsi adalah proses yang berkaitan dengan masuknya pesan atau informasi kedalam otak manusia, melalui persepsi manusia terus menerus mengadakan hubungan dengan lingkungannya.

2. Asrori (2009:214) mengungkapkan bahwa pengertian persepsi adalah proses individu dalam menginterprestasikan,

mengorganisasikan dan memberi makna terhadap stimulus yang berasal dari lingkungan di mana individu itu berada yang merupakan hasil dari proses belajar dan pengalaman.

Berdasarkan beberapa pendapat di atas, maka dapat disimpulkan bahwa persepsi merupakan anggapan seseorang mengenai suatu obyek yang diterima oleh panca inderanya yang kemudian di terjemahkan melalui perbuatan.

Kecerdasan majemuk pertama kali dikembangkan oleh Howard Gardner, Ph. D yang merupakan seorang ahli psikologi dan Professor Pendidikan di Universitas Harvard. Dalam bukunya Frames of Minds tahun 1983, ia telah mengembangkan kecerdasan majemuk yang terdapat pada diri manusia. Kecerdasan menurut Gardner (2011: 28) adalah kemampuan dalam memecahkan masalah atau menciptakan produk yang dihargai dalam satu atau lebih budaya. Kecerdasan majemuk merupakan 
teori yang menunjukkan bahwa setiap anak punya kecenderungan kecerdasan dari delapan kecerdasan (Chatib, 2014: 89). Hal ini berbeda sekali dengan pandangan tradisional yakni hanya ada dua kecerdasan saja pada manusia yang diukur dengan angka (IQ). Terdapat sembilan kecerdasan menurut Gardner (2011), yaitu Verballinguistic intelligence (Kecerdasan verballinguistik), Logical-mathematical intelligence (Kecerdasan Logismatematis), Spatial-visual intelligence (Kecerdasan spasial-visual), Bodilykinesthetic intelligence (Kecerdasan Kinestetik-jasmani), Musical intelligences (Kecerdasan musik), Interpersonal intelligence (kecerdasan interpersonal), Intrapersonal intelligences (kecerdasan intrapersonal), Naturalist intelligence (kecerdasan naturalis), Existential intelligence (Kecerdasan eksistensial).

Setiap orang memiliki kecerdasan yang berbeda-beda, sehingga perlakuan yang diberikan juga berbeda. Sebagai contoh, dalam satu keluarga memiliki beberapa anak dengan kecerdasan yang berbeda, sehingga perlakuan orang tua terhadap anak-anaknya tidak dapat disamakan satu sama lainnya. Orang tua perlu menjajaki potensi kecerdasan setiap anaknya agar pendekatan yang digunakan.Pada tahun 1983 seorang ahli psikologi perkembangan Howard Gardner telah mengembangkan teori kecerdasan majemuk (multiple intelligences(MI)).

Kecerdasan majemuk telah banyak diterapkan di sekolah, salah satunya SD Labschool FIP UMJ memiliki misi yaitu membangun kecerdasan anak melalui kecerdasan majemuk. Misi tersebut direalisasikan melalui program unggulan ekstra kurikuler, misalnya Seni Membaca Al Qur'an, Komputer, Robotik, Bahasa
Inggris, Fun Cooking, Tari, Catur, Musik Biola, Paduan Suara, Angklung, dan masih banyak lainnya yang mengasah multi kecerdasan anak. Disamping itu, Misi ini juga harus didukung oleh orang tua siswa agar anak benar-benar memilih ekskul yang dia inginkan dengan benar, bukan karena paksaan orang tua mereka atau ikutikutan.

Hessel (2005) meneliti mengenai persepsi orang tua dan guru terhadap kecerdasan majemuk (MI) anak-anak. Dia menyimpulkan bahwa memahami faktorfaktor yang berkontribusi terhadap persepsi orang tua dan guru tentang kecerdasan majemuk anak-anak akan meningkatkan pemahaman tentang tingkat kecerdasan majemuk pada anak-anak. Sehingga perlu untuk pihak sekolah SD Labschool FIP UMJ untuk mengetahui bagaimana persepsi orang tua murid mengenai kecerdasan anaknya. Kecerdasan majemuk yang di amati bersumber dari 8 kecerdasan majemuk Howard Gardner ditambah dengan kecerdasan spiritual Ian Marshall dan Danah Zohar. Adapun tujuan dari penelitian yang akan dilakukan adalah mendeskripsikan persepsi orang tua terhadap kecerdasan anaknya.

\section{METODE PENELITIAN}

Penelitian ini mengenai analisis persepsi orang tua siswa SD Labschool FIP UMJ terhadap kecerdasan anaknya dengan membandingkan antara harapan/dukungan dan persepsi mereka menggunakan metode survey. Jenis penelitian yang digunakan dalam penelitian ini adalah penelitian kuantitatif. Pendekatan ini digunakan untuk mengidentifikasi secara deskriptif bagaimana persepsi orang tua terhadap kecerdasan anaknya. Orang tua harus benar-benar mengenal bagaimana 
karakteristik kecerdasan anaknya agar stimulasi yang diberikan kepada anaknya tepat untuk perkembangan anaknya.

\section{Populasi dan Sampel}

Populasi dalam penelitian ini adalah keseluruhan siswa SD Labschool FIP UMJ, yaitu siswa kelas 1 hingga kelas 6, yang berjumlah 257. SD Labschool FIP UMJ terdiri dari 13 kelas, yaitu kelas 1.1, $1.2,1.3,2.1,2.2,2.3,3.1,3.2,4.1,4.2,5.1$, 5.2, dan kelas 6 .

Penarikan sampel dalam penelitian ini menggunakan teknik penarikan bertujuan (Purpossive Sampling), dengan kriteria:

1. Kelas yang memiliki siswa dengan kecerdasan majemuk yang heterogen.

2. Kelas tinggi yang siswanya sudah bisa memilih/menemukan bakatnya sendiri (kelas 4/5/6).

Berdasarkan kriteria di atas kelas yang dipilih untuk dijadikan sampel adalah kelas 4.2 dan 5.1. Berikut data sampel yang terpilih

Tabel 1. Data Sampel Penelitian

\begin{tabular}{ccc}
\hline No. & Kelas & Jumlah \\
\hline 1 & Kelas 4.2 & 22 \\
2 & Kelas.5.1 & 16 \\
\hline & Total & $\mathbf{3 8}$ \\
\hline
\end{tabular}

\section{Instrumen Penelitian}

Instrumen penelitian yang digunakan dalam penelitian ini meliputi angket kuesioner, dokumentasi, dan wawancara. Angket yang digunakan dalam penelitian ini menggunakan skala likert. Data penelitian ini diperoleh dari jawaban responden terhadap pertanyaan yang diajukan, menyangkut persepsi dan dukungan responden terhadap berbagai variable kecerdasan majemuk. Responden diminta untuk memberikan persepsi dan dukungan mereka dengan memilih salah satu dari alternatif dari keempat jawaban yang tersedia. Adapun definisi operasional dari persepsi dan dukungan orang tua adalah:

a. Persepsi (X)

Ukuran persepsi orang tua mengenai performa kecerdasan majemuk anak, dengan skala likert:
(1) STS : Sangat tidak setuju
(2) TS : Sangat setuju
(3) $\mathrm{R}$ : Ragu-ragu
(4) $\mathrm{S} \quad$ : Setuju
(5) SS : Sangat setuju

b. Dukungan (Y)

Ukuran dukungan orang tua terhadap kecerdasan majemuk anak, dengan skala likert:
(1) STM : Sangat Tidak Mendukung
(2) TM : Tidak Mendukung
(3) R : Ragu-ragu
(4) M : Mendukung
(5) SM : Sangat Mendukung

Aspek-aspek variabel kecerdasan yang digunakan dalam penelitian ini adalah (Armstrong, 2009):

Tabel 2. Aspek-aspek dan Indikator Variabel Kecerdasan Majemuk

\begin{tabular}{llll}
\hline \multicolumn{1}{c}{ Aspek } & \multicolumn{3}{c}{ Indikator } \\
\hline $\begin{array}{l}\text { Verbal-linguistic } \\
\text { intelligence (Kecerdasan }\end{array}$ & a. Dapat menulis lebih baik dibandingkan anak \\
verbal-linguistik) & seusianya & \\
& b. Suka berdongeng atau bercanda dan bercerita & \\
& c. Mengingat nama, tempat, dll dengan baik \\
& d. Menyukai permainan kata & \\
& e. Suka membaca buku \\
\hline
\end{tabular}


FIBONACCI : Jurnal Pendidikan Matematika dan Matematika. Vol. 4 (1), pp: 1-16.

\begin{tabular}{|c|c|}
\hline Aspek & Indikator \\
\hline & $\begin{array}{l}\text { f. Mengucapkan kata dengan benar (atau dalam } \\
\text { kemampuan berbiacara lebih baik dibandingkan anak } \\
\text { seusianya) } \\
\text { g. Suka mendengarkan kata-kata yang diucapkan (cerita, } \\
\text { komentar dalam radio, dan buku bersuara) } \\
\text { h. Memiliki perbendaharaan kosa kata lebih banyak } \\
\text { dibandingkan anak seusianya } \\
\text { i. Lebih banyak berkomunikasi secara verbal }\end{array}$ \\
\hline $\begin{array}{l}\text { Logical-mathematical } \\
\text { intelligence (Kecerdasan } \\
\text { Logis-matematis) }\end{array}$ & $\begin{array}{l}\text { a. Sering bertanya tentang cara kerja sesuatu } \\
\text { b. Suka bermain dengan angka } \\
\text { c. Suka pelajaran matematika } \\
\text { d. Tertarik permainan matematika dan komputer } \\
\text { e. Suka permainan catur dan permainan strategi lainnya } \\
\text { f. Suka bermain puzzle dan permainan otak lainnya } \\
\text { g. Suka menempatkan sesuatu sesuai kategori } \\
\text { h. Suka bereksperimen dalam pelajaran ipa } \\
\text { i. Menunjukkan ketertarikan terhadap ipa } \\
\text { j. Baik dalam pemecahan masalah secara logic }\end{array}$ \\
\hline $\begin{array}{l}\text { Spatial-visual intelligence } \\
\text { (Kecerdasan spasial-visual) }\end{array}$ & $\begin{array}{l}\text { a. Menceritakan arti gambar visual dengan jelas } \\
\text { b. Membaca peta, grafik, diagram dengan mudah } \\
\text { disbanding teks } \\
\text { c. Sering melamun } \\
\text { d. Suka kegiatan seni } \\
\text { e. Bagus dalam menggambar } \\
\text { f. Suka menonton film, slide, dan presentasi visual } \\
\text { lainnya } \\
\text { g. Suka main puzzle, labirin, atau permainan serupa } \\
\text { lainnnya } \\
\text { h. Suka membangun bangunan } 3 \text { dimensi (contoh: } \\
\text { membuat bangunan dengan lego, pasir, dll) } \\
\text { i. Suka dengan gambar dibandingkan kata-kata saat } \\
\text { membaca buku } \\
\text { j. Suka menggambar acak pada buku pelajaran, buku } \\
\text { tulis, dan bahan material yang lain. }\end{array}$ \\
\hline $\begin{array}{l}\text { Bodily-kinesthetic } \\
\text { intelligence (Kecerdasan } \\
\text { Kinestetik-jasmani) }\end{array}$ & $\begin{array}{l}\text { a. Baik dalam satu atau lebih bidang olahraga } \\
\text { b. Bergerak-gerak, mengetuk-ngetuk jari saat duduk } \\
\text { lama } \\
\text { c. Pintar meniru mimik dan gerakan orang lain } \\
\text { d. Suka membongkar benda dan membangunnya } \\
\text { kembali } \\
\text { e. Suka memegang semua benda yang baru dilihatnya } \\
\text { f. Menyukai lari, lompat, dan bergulat. } \\
\text { g. Memiliki bakat dalam membuat kerajinan } \\
\text { h. Suka dramatis (berlebihan) dalam berkespresi } \\
\text { i. Heboh saat berpikir atau bekerja } \\
\text { j. Suka bermain dengan lilin atau memainkan jari } \\
\text { (contohnya menggambar dengan jari) }\end{array}$ \\
\hline al intell & a. Memberitahu anda saat suara musik terasa tidak pas \\
\hline
\end{tabular}




\begin{tabular}{|c|c|}
\hline Aspek & Indikator \\
\hline (Kecerdasan musik) & $\begin{array}{l}\text { atau mengganggu } \\
\text { b. Pintar mengingat melodi lagu } \\
\text { c. Pandai bernyanyi } \\
\text { d. Suka bermain alat music atau menyanyi dalam paduan } \\
\text { suara } \\
\text { e. Memiliki ritme dalam berbicara dan bergerak } \\
\text { f. Suka bersenandung sendiri } \\
\text { g. Suka mengetuk jari di meja saat bekerja } \\
\text { h. Sensitif terhadap suara } \\
\text { i. Langsung berespon saat mendengar suara musik } \\
\text { j. Suka menyanyikan lagu yang dia dengar }\end{array}$ \\
\hline $\begin{array}{l}\text { Interpersonal intelligence } \\
\text { (kecerdasan interpersonal) }\end{array}$ & $\begin{array}{l}\text { a. Menikmati bersosialisasi dengan sebaya } \\
\text { b. Memiliki kemampuan memimpin } \\
\text { c. Suka memberikan nasihat saat teman memiliki } \\
\text { masalah } \\
\text { d. Pandai bersosialisasi dengan siapapun } \\
\text { e. Ikut serta dalam klub, komite, dan organisasi non } \\
\text { formal } \\
\text { f. Suka mengajar teman yg lain } \\
\text { g. Suka bermain game dengan teman-teman } \\
\text { h. Memiliki dua atau lebih teman dekat } \\
\text { i. Memiliki rasa empati yg baik } \\
\text { j. Dicari orang lain saat dibutuhkan }\end{array}$ \\
\hline $\begin{array}{l}\text { Intrapersonal intelligences } \\
\text { (kecerdasan intrapersonal) }\end{array}$ & $\begin{array}{l}\text { a. Menunjukkan rasa mandiri atau kemauan yang kuat } \\
\text { b. Mengetahui kekurangan dan kelebihan diri sendiri } \\
\text { c. Lebih baik sendiri saat belajar atau bermain } \\
\text { d. Memiliki kesenangan atau hobi yang tidak banyak ia } \\
\text { biacarakan ke orang lain } \\
\text { e. Mampu mengatur diri sendiri dengan baik } \\
\text { f. Lebih menyukai bekerja sendiri dibanding } \\
\text { berkelompok } \\
\text { g. Akurat dalam mengekspresikan apa yang dia rasakan } \\
\text { h. Dapat belajar dari kesalahan dan kesuksesan di masa } \\
\text { i. Memiliki rasa percaya diri yang baik }\end{array}$ \\
\hline $\begin{array}{l}\text { Naturalist intelligence } \\
\text { (kecerdasan naturalis) }\end{array}$ & $\begin{array}{l}\text { a. Suka membicarakan hal favoritnya seperti hewan, } \\
\text { tempat alam yang disukai saat bercerita/curhat } \\
\text { b. Menyukai wisata alam ke kebun binatang atau museum } \\
\text { sejarah } \\
\text { c. Menunjukkan sensitivitas pada formasi alam (misalnya } \\
\text { saat berjalan ke luar dia akan melihat awan, gunung, } \\
\text { dll, atau kalo sedang berjalan diperkotaan dia akan } \\
\text { melihat yang sedang popular, misal model sepatu, gaya } \\
\text { mobil, dll) } \\
\text { d. Suka air dan merawat tanaman di rumah } \\
\text { e. Menyukai bermain di taman hewan, akuarium atau di } \\
\text { taman }\end{array}$ \\
\hline
\end{tabular}




\begin{tabular}{|c|c|}
\hline Aspek & Indikator \\
\hline & $\begin{array}{l}\text { f. Senang saat belajar tentang ekologi, alam, tanaman dan } \\
\text { hewan } \\
\text { g. Suka melakukan tugas-tugas yang berkaitan dengan } \\
\text { alam seperti melihat burung, mengoleksi kupu-kupu } \\
\text { atau serangga, mempelajari pohon atau memelihara } \\
\text { hewan } \\
\text { h. Baik saat berbicara mengenai topik yang berkaitan } \\
\text { dengan sistem kehidupan. }\end{array}$ \\
\hline $\begin{array}{l}\text { Spiritual intelligence } \\
\text { (Kecerdasan Spiritual) } \\
\text { (Chatib, 2014: 98). }\end{array}$ & $\begin{array}{l}\text { a. Senang berdiskusi mengenai permasalahan agama dan } \\
\text { solusinya } \\
\text { b. Selalu meminta maaf ketika berbuat salah. } \\
\text { c. Spontanitas, termotivasi secara internal. } \\
\text { d. Kasih Sayang. } \\
\text { e. Mempertanyakan secara mendasar. } \\
\text { f. Menata kembali dalam gambaran besar. } \\
\text { g. Teguh dalam kesulitan. }\end{array}$ \\
\hline
\end{tabular}

\section{Uji Coba Instrumen}

Sebelum angket di gunakan untuk mengambil data, angket perlu dilakukan uji instrumen terlebih dahulu. Adapun uji instrumen yang digunakan dalam penelitian ini adalah uji validitas dan uji reliabilitas. Kedua uji instrumen ini diuji melalui program SPSS IBM Statistics 22 for Windows.

\section{Uji Validitas}

Uji ini digunakan untuk mengukur tingkat kevalidan dan kesahihan suatu instrument. Metode pengambilan keputusan pada uji validitas menggunakan batasan korelasi item-total adalah 0.25 (Singh et al., 2016). Nilai $r$ dapat diketahui dengan menggunakan rumus korelasi:

$$
r=\frac{n \sum x y-\sum x \sum y}{\sqrt{\left(n \sum x^{2}-\left(\sum x\right)^{2}\right)\left(n \sum y^{2}-\left(\sum y\right)^{2}\right)}}
$$

\section{Keterangan:}

$r \quad$ : Nilai korelasi

$x \quad$ : nilai skor pada masing-masing indikator

$y \quad$ : total nilai skor responden

$n \quad$ : jumlah responden

2. Uji Reliabilitas
Uji ini bertujuan untuk mengukur konsistensi suatu instrumen penelitian. Uji ini menggunakan metode cronbach alpha dan pengambilan keputusan menggunakan nilai alpha dari setiap variable, dikatakan valid jika nilai alpha tersebut $\geq 0,6$. Rumus Alpha Cronbach adalah sebagai berikut:

$$
\alpha=\left(\frac{k}{k-1}\right)\left(1-\frac{\sum \sigma_{b}^{2}}{\sigma_{t}^{2}}\right)
$$

Keterangan:

$$
\begin{array}{ll}
\alpha & : \text { Reliabilitas instrumen } \\
k & \text { : Banyaknya indikator } \\
\sum \sigma_{b}^{2} & \text { : Total varian indikator } \\
\sigma_{t}^{2} & \text { : varian total }
\end{array}
$$

\section{Teknik Analisis Data}

Teknik analisa data yang digunakan dalam penelitian ini adalah analisis deskriptif dan Importance-Performance Analysis. Analisis deskriptif digunakan untuk mengetaui bagaimana karakteristik dari responden (orang tua), sehingga dapat menggambarkan secara umum karakteristik dari orang tua SD Labschool FIP UMJ yang diteliti. Perumusan masalah dalam penelitian ini dianalisis dengan menggunakan Importance-Performance 
Analysis (IPA) atau analisis tingkat dukungan/harapan orang tua dan performa kecerdasan anak. IPA pertama kali diusulkan dan diperkenalkan oleh Martilla dan James pada tahun 1977 sebagai sarana untuk mengukur kepuasan pelanggan terhadap produk atau jasa (Silva dan Fernandes, 2011).

Dalam penelitian ini, analisis IPA digunakan untuk mengukur persepsi orang tua terhadap kecerdasan anaknya, yaitu melihat tingkat kesesuaian dengan membandingkan skor performa kecerdasan anak dengan skor tingkat dukungan orang tua mengenai kecerdasan anaknya. Tingkat kesesuaian responden inilah yang akan menentukan urutan prioritas peningkatan indikator-indikator yang mempengaruhi kepuasan orang tua mengenai kecerdasan anaknya.

Analisis ini menggunakan rumus (Supranto, 1997):

$\bar{X}_{j}=\frac{\sum_{i=1}^{n} X_{i}}{n} \quad$ dan $\quad \overline{\bar{X}}_{l}=\frac{\sum_{i=1}^{k} \bar{X}_{j}}{k u}$

\begin{tabular}{l|ll} 
& Prioritas Utama & Pertahankan Prestasi \\
Quadran II & Quadran I \\
& Prioritas & Berlebihan \\
Quadran III & Quadran IV
\end{tabular}

Kepuasan/Performa

Keterangan: dan

$\bar{Y}_{j}=\frac{\sum_{i=1}^{n} Y_{i}}{n} \quad$ dan $\quad \overline{\bar{Y}}_{l}=\frac{\sum_{i=1}^{n} \bar{Y}_{i}}{n}$

$\overline{\bar{X}}_{l}$ : Rata-rata skor performa kecerdasan ke- $l, l=1,2, \ldots, 9$

$\bar{X}_{j}$ : Rata-rata skor performa kecerdasan indikator ke-j, $j=1,2, \ldots, k$

$X_{i}$ : Skor performa kecerdasan anak responden ke- $i, i=1,2, \ldots, n$

$\overline{\bar{Y}}_{l}$ : Rata-rata skor kepentingan kecerdasan ke- $l$

$\bar{Y}_{j} \quad$ : Rata-rata skor kepentingan indikator ke-j

$Y_{i}$ : Skor kepentingan indikator pada responden ke- $i$

$n$ : Jumlah responden

Pemodelan IPA dibagi ke dalam 4 kuadran, yaitu dengan sumbu-Y sebagai variabel harapan (dukungan), sedangkan sumbu-X sebagai variabel penilaian performa kecerdasan anak. Empat kuadran IPA digambarkan pada Gambar 1 berikut:

Gambar 1. Kuadran IPA

Keterangan:

I. Menunjukkan kecerdasan pokok yang telah berhasil dilaksanakan anak, untuk itu wajib dipertahankannya. Dianggap sangat penting dan sangat bagus performa kecerdasannya.

II. Menunjukkan indikator yang dianggap mempengaruhi kepuasan orang tua, termasuk indikatorindikator kecerdasan yang dianggap 
sangat penting bagi orang tua, namun anak belum memiliki performa kecerdasan sesuai keinginan orang tua, sehingga belum sesuai harapan orang tuanya.

III. Menunjukkan beberapa indikator yang kurang penting pengaruhnya bagi orang tua, performa kecerdasan anak juga biasa-biasa saja. Kecerdasan pada wilayah ini dianggap kurang penting dan kurang memuaskan.

IV. Menunjukkan indikator yang dianggap kurang penting bagi orang tua, akan tetapi kemampuan anak melebihi dari yang diharapkan orang tua. Indikator pada wilayah ini dianggap kurang penting tetapi sangat memuaskan bagi orang tua.

\section{HASIL DAN PEMBAHASAN}

SD Labschool FIP UMJ adalah Lembaga Pendidikan Tingkat Dasar yang mengembangkan multiple intelligence dengan memfokuskan pada Keunggulan Karakter, Keunggulan Ilmu Pengetahuan, dan Keunggulan Tahfizh.

\section{Deskripsi Data Responden}

Responden yang dijadikan sampel dalam penelitian ini merupakan orang tua dari siswa SD Labschool FIP UMJ. Ukuran sampel yang valid dalam penelitian ini sebanyak 33 responden yang kurang dari sampel yang telah ditentukan, yaitu 38 orang tua dari siswa. Hal ini berarti terdapat 5 kuesioner yang tidak valid/tidak dikembalikan oleh responden.

Adapun karakteristik orang tua siswa yang menjadi responden dalam penelitian ini sebagian besar berusia 36-45 tahun, yaitu sebanyak $73 \%$. Hal ini berarti bahwa rata-rata orang tua siswa SD
Labschool berada pada usia pertengahan atau paruh baya. Sedangkan 18\% dari responden masih berusia muda, yaitu di bawah 35 tahun. Selain itu, 79\% responden merupakan wanita atau ibu dari siswa SD Labschool FIP UMJ, sisanya 21\%, merupakan persepsi ayah terhadap kecerdasan majemuk anaknya.

Sebagian besar responden juga merupakan seorang ibu pekerja, yaitu sebanyak 64\%. Sebagian kecilnya bekerja sebagai PNS (Pegawai Negeri Sipil). Responden yang tidak bekerja atau menjadi ibu rumah tangga sebanyak 46\%, angka ini paling banyak dibandingkan kategori pekerjaan lainnya. Sebagian besar responden juga memiliki tingkat pendidikan yang tinggi. Sebanyak 58\% responden memiliki tingkat pendidikan S1 sedangkan S2 sebanyak 9\%. 33\% sisanya merupakan orang tua yang berpendidikan di bawah S1. Hal ini berarti bahwa sebagian besar orang tua siswa sudah lebih baik memperlakukan anaknya dengan positif dan bersikap terbuka dengan kemampuan anaknya.

$70 \%$ responden memiliki penghasilan lebih dari 5 juta. penghasilan merupakan salah satu dukungan dari orang tua untuk pendidikan anaknya. Sebagian besar orang tua sudah memiliki penghasilan yang mapan untuk mendukung pendidikan anaknya. Berdasarkan data dari dua kelas yang dijadikan sampel, ternyata jenis kelamin untuk laki-laki dan perempuan berimbang yaitu 50:50.

\section{Validasi Instrumen}

Uji validitas dan reliabilitas untuk instrumen dilakukan di kelas 5.2 SD Labschool FIP UMJ. Uji ini dilakukan terhadap 15 responden, yang merupakan orang tua siswa. Pada Tabel 3 terlihat bahwa terdapat 18 indikator pada instrumen 
yang tidak valid/dikeluarkan dari 88 indikator yang diujikan, karena memiliki nilai korelasi skor antara indikator dalam aspek dengan total aspek lebih kecil dari 0,25 .

Tabel 3. Indikator yang Tidak Valid

\begin{tabular}{lcc}
\hline \multicolumn{1}{c}{ Indikator } & Dukungan & Persepsi \\
\hline Verbal 1 & -0.198 & -0.449 \\
Logika 10 & 0.252 & 0.083 \\
Spasial 3 & -0.099 & 0.311 \\
Spasial 4 & 0.338 & -0.151 \\
Spasial 6 & 0.469 & -0.085 \\
Spasial 9 & 0.531 & 0.155 \\
Kines 2 & -0.011 & 0.089 \\
Kines 3 & 0.32 & 0.209 \\
Kines 5 & 0.337 & -0.003 \\
Kines 6 & 0.21 & 0.49 \\
Kines 8 & 0.614 & -0.059 \\
Kines 9 & 0.416 & 0.133 \\
Musik 8 & 0.752 & 0.146 \\
Intra 1 & 0.166 & 0.612 \\
Intra 3 & 0.222 & 0.231 \\
Intra 4 & 0.179 & 0.124 \\
Intra 5 & 0.457 & 0.147 \\
Intra 6 & 0.142 & 0.4 \\
\hline
\end{tabular}

\section{Eksplorasi Persepsi Orang Tua}

Tingkat Kesesuaian Total $\left(T k_{i}\right.$ Total) antara persepsi (X) dengan dukungan (Y) adalah sebesar 94,9 \%. Hal ini berarti bahwa persepsi atau performa kecerdasan majemuk anak sudah sesuai dengan dukungan orang tua, yaitu sebesar 94,9\%. Namun harus diselidiki lebih jauh lagi dengan analisis SERVQUAL.

$$
\sum X_{i}=9663 \text { dan } \sum Y_{i}=10182
$$

$T k_{i}$ Total $=\frac{\sum X_{i}}{\sum Y_{i}} \times 100 \%$

$$
=\frac{9663}{10182} \times 100 \%=94,9 \%
$$

Hasil ini juga didukung dengan grafik cartesius SERVQUAL pada Gambar 2 merupakan grafik cartesius SERVQUAL untuk 9 kecerdasan yang diteliti. Kecerdasan yang berada di Kuadran II adalah kecerdasan logika dan matematis. Kecerdasan ini merupakan prioritas utama yang perlu diperhatikan, baik orang tua maupun pihak sekolah. Karena hal ini berarti bahwa orang tua masih menganggap cerdas dalam logika dan matematika itu sangat penting, namun performa kecerdasan matematis anaknya belum sesuai dengan yang diharapkannya. Hal ini mungkin karena anaknya lebih dominan di kecerdasan majemuk lainnya.

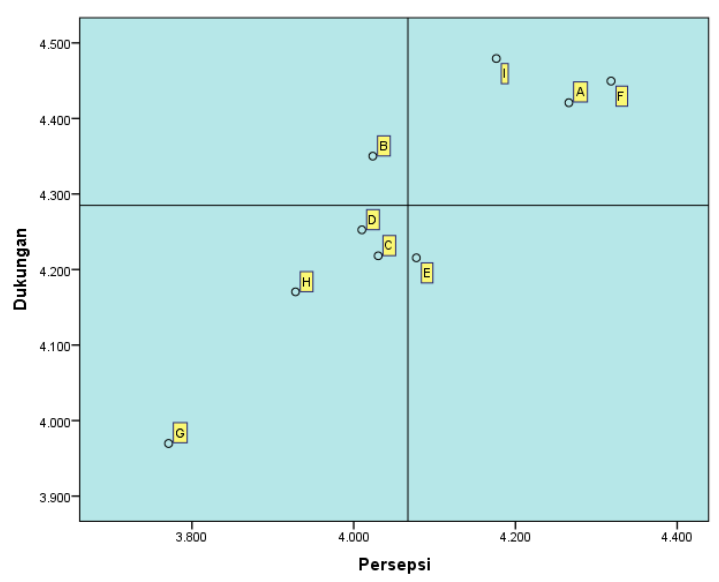

Gambar 2. Grafik Cartesius SERVQUAL Indikator Kecerdasan Majemuk Anak 
FIBONACCI : Jurnal Pendidikan Matematika dan Matematika. Vol. 4 (1), pp: 1-16.

Perhatikan juga kuadran I, kecerdasan yang masuk dalam kuadran ini adalah kecerdasan bahasa, kecerdasan interpersonal dan kecerdasan spiritual. Kecerdasan yang berada dalam kuadran ini berarti harus dipertahankan baik itu bagi orang tua, siswa, dan pihak sekolah. Hasil ini juga didukung oleh persepsi orang tua mengenai kecerdasan anaknya yang dirangkum dalam Tabel 4. Ketiga kecerdasan majemuk tersebut memiliki persentase dukungan tertinggi dibanding kecerdasan lainnya. 67,65\% orang tua sangat mendukung kecerdasan spiritual anaknya, dan kecerdasan ini berada pada tingkatan pertama. Sedangkan pada tingkatan kedua dan ketiga adalah kecerdasan interpersonal dan kecerdasan berbahasa, yaitu secara berurutan $50 \%$ dan $41,18 \%$ orang tua mendukung kedua kecerdasan tersebut.

Tabel 4. Persepsi Orang Tua Terhadap Kecerdasan Majemuk

\begin{tabular}{lc}
\hline \multicolumn{1}{c}{ Kecerdasan } & Persentase Dukungan \\
\hline Kecerdasan Spiritual & $67.65 \%$ \\
Kecerdasan Interpersonal & $50.00 \%$ \\
Kecerdasan Linguistik/Berbahasa & $41.18 \%$ \\
Kecardasan Kinestetik-Jasmani & $29.41 \%$ \\
Kecerdasan Intrapersonal & $29.41 \%$ \\
Kecerdasan Visual & $26.47 \%$ \\
Kecerdasan Matematik & $23.53 \%$ \\
Kecerdasan Musik & $17.65 \%$ \\
Kecerdasan Naturalis & $2.94 \%$ \\
\hline
\end{tabular}

\section{Analisis Data: Analisis IPA}

\section{Kuadran I: Pertahankan (Maintain)}

\section{Kecerdasan Bahasa}

Skor kesesuaian indikator kecerdasan bahasa yang bernilai positif adalah "anak lebih banyak berkomunikasi secara verbal", namun selisihnya tidak terlalu signifikan yaitu sebesar 0,061. Hal ini berarti bahwa performa kecerdasan anak pada indikator ini baik/sesuai dengan dukungan dari orang tua. Kecerdasan bahasa yang perlu diperhatikan juga adalah "Selalu mempertimbangkan kata-kata yang diucapkan orang lain, sebelum diekspresikan". Indikator ini mempunyai nilai negatif yang cukup besar, yaitu $-0,303$ dan indikator ini juga berada pada kuadran II. Menurut Marisa (2015) bicara adalah pengucapan, yang menunjukkan keterampilan seseorang mengucapkan suara dalam suatu kata, sedangkan bahasa berarti menyatakan dan menerima informasi dalam suatu cara tertentu.

Indikator "suka membaca buku" masuk dalam kuadran I, yang artinya harus dipertahankan, namun juga diperhatikan bahwa skor kesesuaiannya bernilai negatif paling besar dari indikator lainnya. Hal ini berarti bahwa performa anak dalam membaca buku masih kurang menurut orang tuanya. SD Labschool FIP UMJ sudah membangun minat baca anak melalui kegiatan literasi sekolah. Namun, perlu dikaji kembali implementasi program tersebut apakah sudah berhasil menumbuhkan minat baca anak. Orang tua juga dapat menumbuhkan minat baca anak salah satunya dengan mengurangi waktu anak-anak bersama gadget. Misalnya, anak yang suka menonton youtube dapat diganti 
dengan buku-buku cerita menarik, majalah, atau apa saja dalam bentuk buku.

2. Kecerdasan Interpersonal

Kecerdasan interpersonal merupakan kemampuan seseorang untuk berhubungan dengan orang-orang disekitarnya sehingga dia bisa merasakan secara emosional. Kecerdasan ini sangat penting untuk kita dapat berhubungan baik dengan sesama makhluk ciptaan Allah SWT. Berdasarkan hasil analisis indikator "Memiliki kemampuan memimpin" berada pada kuadran 2 atau prioritas utama. Dan selain indikator ini harus dipertahankan baik oleh orang tua maupun pihak sekolah. Indikator ini juga memiliki nilai skor kesesuaian yang negatif dan lebih besar dibandingkan indikator lainnya, yaitu 0,394. Hal ini berarti bahwa performa kemampuan memimpin anak belum sesuai dengan dukungan dari orang tuanya yang mendukung anaknya untuk memiliki kemampuan memimpin. Kemampuan ini memang tidak semua orang memilikinya, namun kemampuan ini dapat diajarkan kepada setiap anak sejak anak masih kecil. Sekolah adalah situs utama di mana pengetahuan dan kompetensi untuk kewarganegaraan dan kepemimpinan siswa dapat diajarkan dan dibudidayakan (Black et al., 2014). Sehingga sekolah sangat berperan dalam pembentukan karakter pemimpin siswa.

3. Kecerdasan Spiritual

Indikator kecerdasan spiritual yang berada pada kuadran II adalah:

1. Memiliki rasa kepedulian dan kepekaan yang tinggi terhadap tumbuh-tumbuhan dilingkunganya.

2. Memiliki rasa kepedulian dan kepekaan yang tinggi terhadap benda-benda alam dilingkunganya.

3. Bersabar dalam menghadapi masalah.

\section{Selalu mempertimbangkan, sebelum mengambil keputusan}

Keempat indikator tersebut mempunyai nilai skor negatif terbesar dibanding indikator yang lain. Perhatikan bahwa indikator pertama dan kedua merupakan indikator rasa peduli anak terhadap alam. Indikator ini masih dianggap kurang performanya bagi orang tua. Begitu juga dengan indikator ke tiga dan empat, yang merupakan tingkat kesabaran anak baik dalam menghadapi masalah maupun mengambil keputusan.

Menunjukkan lingkungan alam dan bermain di luar ruangan bermanfaat bagi anak-anak dalam banyak hal, yaitu mengembangkan kreativitas, permainan simbolik, pemecahan masalah dan intelektual anak, selain itu juga dapat mengembangkan keterampilan motorik kasar, koordinasi mata-tangan dan membantu mencegah obesitas anak (Department of Education and Training Victoria, 2013). Mengenalkan lingkungan alam sambil mengajak anak bertafakur kepada Allah SWT merupakan salah satu untuk menumbuhkan peduli anak terhadap alam.

\section{Kuadran II: Prioritas Utama (Under Act)}

Kecerdasan yang berada dalam kuadran ini hanya satu yaitu kecerdasan Logika dan Matematis. Kecerdasan ini merupakan kecerdasan yang masuk dalam kuadran II atau prioritas utama yang perlu diperhatikan. Tabel 5 menunjukkan bahwa semua indikator kecerdasan logis dan matematis bernilai negatif atau performa kecerdasan anak belum sesuai dengan harapan/dukungan orang tua. "Suka pelajaran matematika" merupakan indikator yang bernilai negatif paling besar diantara indikator lainnya yaitu $-0,515$, begitu juga 
Tabel 5. Skor Kesesuaian Antara Persepsi Dan Dukungan Orang Tua Terhadap Kecerdasan Majemuk

\begin{tabular}{lccc}
\hline Indikator & Persepsi & Dukungan & Skor Kesesuaian \\
\hline a. Sering bertanya tentang cara kerja sesuatu & 4.545 & 4.697 & -0.152 \\
b. Suka bermain dengan angka & 3.970 & 4.303 & -0.333 \\
c. Suka pelajaran matematika & 3.818 & 4.333 & -0.515 \\
d. Tertarik permainan matematika dan & 4.061 & 4.394 & -0.333 \\
$\quad \begin{array}{l}\text { computer } \\
\text { e. Suka permainan catur dan permainan }\end{array}$ & 3.879 & 4.152 & -0.273 \\
$\quad \begin{array}{l}\text { strategi lainnya } \\
\text { f. Suka bermain puzzle dan permainan otak }\end{array}$ & 4.152 & 4.455 & -0.303 \\
$\quad \begin{array}{l}\text { lainnya } \\
\text { g. Suka menempatkan sesuatu sesuai }\end{array}$ & 3.939 & 4.182 & -0.242 \\
$\quad$ kategori & 3.939 & 4.424 & -0.485 \\
h. Menunjukkan ketertarikan terhadap ipa & & 4.212 & -0.303 \\
i. Baik dalam pemecahan masalah secara & 3.909 & & \\
\hline
\end{tabular}

Tabel 5 juga menyimpulkan hal yang sama seperti pada Gambar 3 yang memperlihatkan bahwa indikator "suka pelajaran matematika" dan "menunjukkan ketertarikan terhadap IPA" menjadi prioritas utama yang harus diperhatikan.
Orang tua dan guru harus bekerja sama untuk membuat siswa menyukai dan tertarik untuk belajar IPA, salah satunya menciptakan proses pembelajaran yang menyenangkan bagi siswa, sesuai dengan karakteristik siswa masing-masing.

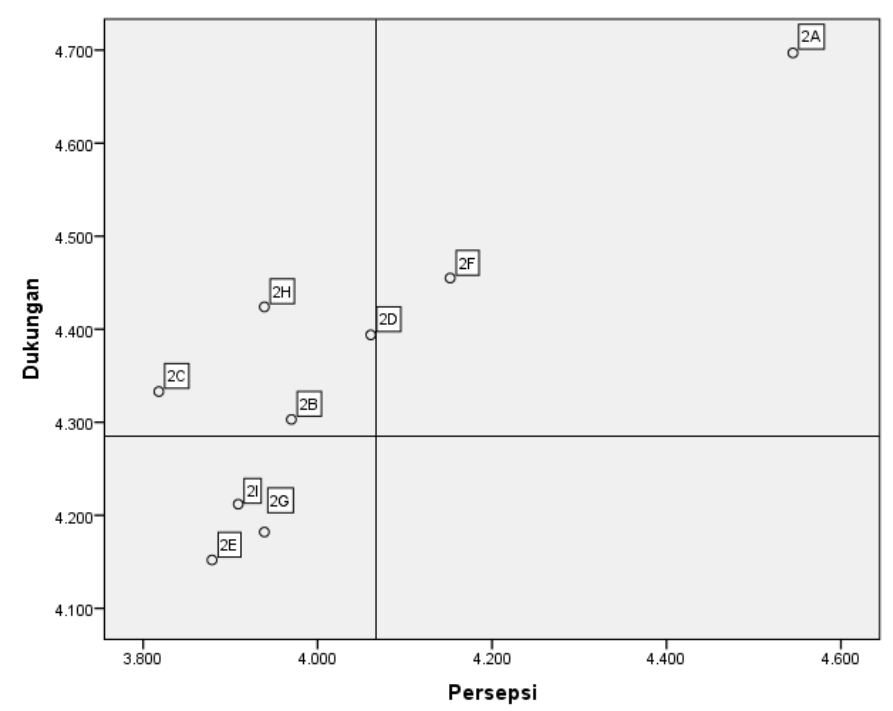

Gambar 3. Grafik Cartesius SERVQUAL Kecerdasan Logika Dan Matematis 


\section{Pembahasan}

Seperti yang telah diketahui bahwa salah satu misi SD Lab School adalah Membangun kecerdasan anak melalui multiple intelligence (kecerdasan majemuk). Misi ini telah terealisasi dalam program unggulan SD Lab School FIP UMJ, khususnya program pengembangan minat dan bakat siswa. Beranekaragam jenis Ekskul yang di persiapkan untuk mengembangkan bakat siswanya. Anak dapat lebih dini mengenal minat dan bakatnya masing-masing. Namun sekolah perlu mengkaji bakat anak sesungguhnya, agar anak bukan hanya sekedar ikut-ikutan saja melainkan karna minat dan bakatnya masing-masing.

Sekolah perlu mendalami karakteristik masing-masing anak, jika benar-benar ingin menerapkan MI di sekolah. Kerjasama yang baik antara orang tua dan guru juga perlu dibangun agar potensi anak dapat digali secara maksimal, sehingga sekolah perlu mengetahui persepsi orang tua siswa mengenai kecerdasan majemuk anaknya. Berdasarkan analisis IPA sebelumnya mengenai persepsi orang tua terhadap kecerdasan majemuk anaknya, kecerdasan majemuk yang dianggap penting dan harus dipertahankan adalah kecerdasan bahasa, interpersonal, dan spiritual.

Sebaliknya, kecerdasan yang harus menjadi perhatian adalah, kecerdasan majemuk logis-matematis yang berada di kuadran II. Orang tua masih mengeluhkan performa kecerdasan tersebut pada anak. Seharusnya sekolah bisa membuat performa kecerdasan logis-matematis anak lebih baik. Tidak dipungkiri bahwa ilmu matematika banyak ditemui dalam kehidupan seharihari, mulai dari bangun tidur hingga kita tertidur kembali. Mungkin sebagian besar anak sudah bisa membaca jam di dinding, meminta kembalian uang ketika berbelanja di toko, dll. Matematika dapat melatih anak dalam berpikir secara analitik dan mengorganisasikan ide lebih baik. Sehingga matematika sangat penting bagi perkembangan pola pikir anak.

"Mengapa tidak semua anak belajar matematika? Mengapa banyak yang menghadapi hambatan signifikan di bidang pendidikan ini? Jika keterampilan dan rasa ingin tahu adalah bawaan, mungkin penjelasannya terletak di lingkungan, atau dengan orang dewasa yang mendukung anak. Untuk mengajarkan matematika kepada anakanak, guru harus melek matematika. Jika para guru yakin dengan apa yang mereka ajarkan, anak-anak lebih mungkin untuk belajar. Telah dikatakan bahwa cara mengajar yang paling efektif adalah mengajarkan konsep-konsep individual secara rinci, sehingga anakanak memahami konsep-konsep tersebut alih-alih hanya mempelajarinya dengan hafalan. Ini berarti bahwa anak-anak dapat menggunakan algoritma dalam berbagai cara daripada hanya dengan cara yang diajarkan. Namun, jika guru itu sendiri menghadapi hambatan untuk pembelajaran mereka dalam subjek ini, mereka tidak akan menanamkan pada anak-anak kepercayaan yang mereka butuhkan untuk menunjukkan kemampuan di bidang ini" (Cairns, 2015).

Berdasarkan kutipan di atas jelas bahwa, anak-anak pada dasarnya memiliki kemampuan matematika dasar, tinggal lingkungannya dapat mengembangkannya atau bahkan menghilangkannya. Ririn dan Mutiarani (2017) menganggap bahwa lingkungan belajar merupakan salah satu faktor yang mempengaruhi motivasi belajar siswa, dan ini harus didukung juga oleh orang tua dan sekolah. 


\section{SIMPULAN}

Persepsi atau performa kecerdasan majemuk anak sudah sesuai dengan dukungan orang tua, yaitu sebesar 94,9\%. Hal ini berarti bahwa orang tua memiliki kepuasan yang tinggi terhadap kecerdasan majemuk anaknya, namun orang tua menganggap bahwa kecerdasan logis- matematis anak masih perlu ditingkatkan. Performa kecerdasan majemuk yang harus dipertahankan adalah kecerdasan spiritual, interpersonal, dan bahasa. Ketiga kecerdasan ini juga merupakan kecerdasan yang dianggap penting bagi orang tua, yaitu dengan besar dukungan lebih dari $41 \%$.

\section{UCAPAN TERIMA KASIH}

Peneliti mengucapkan terimakasih kepada ketua Lembaga Penelitian dan Pengabdian Masyarakat (LPPM) UMJ yang telah mengizinkan dan mendanai peneliti untuk melakukan penelitian ini. Selain itu, peneliti juga berterimakasih kepada Kepala sekolah SD Labschool FIP UMJ beserta guru-guru yang dengan senang hati membantu dalam pengambilan data dalam penelitian ini.

\section{DAFTAR PUSTAKA}

Asrori, M. 2009. Psikologi Pembelajaran. Bandung: CV Wacana Prima

Amstrong, T. 2003. Sekolah Para Juara: Menerapkan Multiple Intelegences di Dunia Pendidikan. Bandung: Kaifa.

A'yun, Q dan Nanik P, Chusniatun. 2015. "Peran Orang Tua dalam Mendidik Anak Usia Dini” (Studi Kasus pada Keluarga Muslim Pelaksana Homeshooling). Jurnal Indigenous. Vol 13 (2), pp: 33-40.

Azwar, S. 2010. Pengantar Psikologi Intelegensi. Yogyakarta. Pustaka Pelajar.

Black, R., Walsh, L., Magee, J., Hutchins, L., Berman, N., \& Groundwater-Smith, S. 2014. Student leadership: a review of effective practice. Canberra: ARACY.

Cairns, E. 2015. Every child is capable of learning maths. [Online] Tersedia: https://www.britishcouncil.org/voices-magazine/every-child-capable-learning-maths [31 Maret 2018].

Chatib, M. 2014. Orang Tuanya Manusia: Melejitkan Potensi dan Kecerdasan dengan Menghargai Fitrah Setiap Anak. Bandung: Kaifa.

Chatib, M. 2017. Semua Anak Bintang: Menggali Kecerdasan dan Bakat Terpendam dengan Multiple Intelligences Research (MIR). Bandung: Kaifa. 
Department of Education \& Training. 2013. Natural Environments. [Online] Tersedia: http://www.education.vic.gov.au/Documents/childhood/providers/regulation/pracnotes naturalenv.pdf [5 April 2018].

Hessel, S. 2005. Teacher and Parent Perceptions of Children's Multiple Intelligences. Tesis tidak diterbitkan. USA: Florida State University.

Noviarni, S. 2015. Orang Tua Juga Perlu Belajar. [Online] Tersedia: http://koransindo.com/page/news/2015-12-29/4/14. [5 Februari 2018].

Silva, FDJH dan Fernandes PO. 2011. Importance-Performance Analysis As A Tool In Evaluating Higher Education Service Quality: The Empirical Results Of Estig (IPB). The 17th IBIMA conference on Creating Global Competitive Economies: A 360degree Approach. Milan, Italy.

Singh, K et al.. 2016. Measure of Positive Psychology: Norms for Test Construction. [Online] tersedia:

https://www.springer.com/cda/content/document/cda_downloaddocument/978813223 6290-c2.pdf [10 Januari 2018].

Slameto. 2010. Belajar dan Faktor-faktor yang Mempengaruhinya. Jakarta : Rineka Cipta

Widiyasari, R dan Mutiarani. 2017. "Penggunaan Metode Structural Equation Modelling untuk Analisis Faktor yang Mempengaruhi Motivasi Belajar Mahasiswa FIP UMJ". Fibonacci: Jurnal Pendidikan Matematika dan Matematika. Vol. 3 (2), pp: 147-160. 